\title{
The influence of supplementing heifer diets with Saccharomyces cerevisiae yeast on the activity of polysaccharidases in the rumen
}

\author{
R. Miltko, B. Kowalik¹, M. Majewska, G. Bełżecki and J. Skomiał \\ The Kielanowski Institute of Animal Physiology and Nutrition, Polish Academy of Sciences, 05-110 Jabłonna, Poland
}

KEY WORDS: yeast, rumen, polysaccharidases activity, heifers

Received: $\quad 10$ March 2015

Revised: $\quad 30$ July 2015

Accepted: 9 September 2015

${ }^{1}$ Corresponding author: e-mail: b.kowalik@ifzz.pl

\begin{abstract}
The effect of live cells and metabolites of the yeast, Saccharomyces cerevisiae, in the diet on the activity of polysaccharidases in the rumen of heifers was examined. The experiment was carried out on three rumen-fistulated heifers. The control diet was composed of $87.5 \%$ meadow hay, $12 \%$ concentrate (barley, rapeseed oilmeal, soyaben oilmeal) and $0.5 \%$ vitamin-mineral mixture. Two experimental rations consisting of the same components were supplemented with either live $S$. cerevisiae yeast or their metabolites. The live yeast were supplied at the rate of $10 \mathrm{~g} \cdot \mathrm{d}^{-1}$, metabolites, at $60 \mathrm{~g} \cdot \mathrm{d}^{-1}$. Cellulolytic activity significantly increased when heifers were fed diets with live yeast in comparison with their metabolites before and $4 \mathrm{~h}$ after feeding. The yeast preparation significantly decreased xylanolytic activity compared with control animals. Amylolytic activity was significantly increased when live yeast were added compared with animals fed the control diet and yeast metabolites at 0 and $4 \mathrm{~h}$ after feeding. The yeast metabolites significantly decreased pectinoIytic activity compared with the control group. Chitinolytic activity was higher in control heifers than in animals fed the experimental diets. Our data suggest that administering a yeast preparation may modify the activity of polysaccharidases in the rumen of heifers.
\end{abstract}

\section{Introduction}

Supplementation of live yeast, Saccharomyces cerevisiae, and its metabolites to diets improves productivity in ruminants (Moharrery and Asadi, 2009). The beneficial effect of these additives has been associated with their ability to alter rumen fermentation and stimulate microbial growth. Preparations containing $S$. cerevisiae promote growth of rumen bacteria, particularly cellulolytic and lactate-utilizing bacteria (Callaway and Martin, 1997; Chaucheyras et al., 1997) and stimulate the growth of rumen ciliates (Kowalik et al., 2011). The stimulatory effect of live $S$. cerevisiae cells on the number of viable bacteria in the rumen appears to be related to the yeast's ability to remove oxygen from rumen fluid, so improving the anaerobic status of rumen digestia (Newbold et al., 1996). On the other hand, yeast metabolites contain: B vitamins, organic acids, amino acids, peptides, esters, as well as mannans and $\beta$-glucans. These compounds probably also support the growth of bacteria (Callaway and Martin, 1997) and protozoa (Kowalik et al., 2011) in the rumen. The efficiency of nutrient utilization by rumen microbes depends on the profile and activity of their enzymes. Ruminal microorganisms have different polysaccharidase activities, e.g., fibrolytic, amylolytic, as well as chitinolytic and pectinolytic. 
Brossard et al. (2006) failed to observe a significant effect of live yeast on the fibrolytic and amylolytic activity in the rumen of sheep. In contrast, Kowalik et al. (2011) showed that a yeast preparation increased the xylanolytic and cellulolytic activity in the rumen of goats. The cell wall of yeast is a rich source of polysaccharides. That of $S$. cerevisiae consists of approximately $30 \%$ to $60 \% 1,3 / 1,6-\beta-D-$ glucans, $40 \%$ mannoproteins (the carbohydrate fraction comprises $90 \%$ ) and $5 \%$ chitin. The yeast structural carbohydrate can be an additional source of energy for microorganisms in the rumen.

The influence of diets supplemented with $S$. cerevisiae on the growth of ruminal microorganisms is fairly well described. The effect of a diet with yeast on polysaccharidase activity is less known. We hypothesize that live yeasts or their metabolites supplemented to the diet may influence rumen enzyme activity by modifying the microorganism population.

The aim of the study was to compare the effect of live S. cerevisiae and its metabolites in the diet on the polysaccharidase activity in the rumen of heifers.

\section{Material and methods}

\section{Animals and feed}

The experiment was carried out on three rumenfistulated Jersey heifers with an average liveweight of $350 \pm 18.6 \mathrm{~kg}$ and similar body condition. The heifers were fed either a control diet $(7.0 \mathrm{~kg} \mathrm{DM} /$ heifer per d) containing $87.5 \%$ meadow hay, $12 \%$ concentrate and $0.5 \%$ vitamin-mineral mixture, or the experimental diets composed of the control diet supplemented with live $S$. cerevisiae (Levucell ${ }^{\circledR} \mathrm{SC}$, S. cerevisiae CNCM I-1077) or its metabolites (Diamond V Mills XP ${ }^{\circledR}$, Cedar Rapids, IA, USA), which were supplied at a dose of 10 and $60 \mathrm{~g} \cdot \mathrm{d}^{-1}$, respectively. The composition of the diet is given in Table 1 . The yeast preparations were administered before the morning feeding into the rumen via the fistula. The daily ration was offered in two equal portions. Because heifers were fed in limited amounts, no orts were observed.

\section{Experimental design and sampling}

The experiment was carried out in a $3 \times 3$ Latin square design. The heifers were assigned to one of three diets (control, live yeast, metabolites) in a cross-over design with $24-d$ periods (i.e. $21 \mathrm{~d}$ of adaptation and $3 \mathrm{~d}$ of sampling). The samples of rumen digesta were collected just before and 2, 4, $8 \mathrm{~h}$ after the morning feeding. The rumen digesta
Table 1. Composition of diet, \% DM

\begin{tabular}{|c|c|c|c|}
\hline \multicolumn{4}{|l|}{ Indices } \\
\hline \multirow{2}{*}{$\begin{array}{l}\text { Ingredients } \\
\text { meadow hay }\end{array}$} & \multicolumn{3}{|c|}{ Chemical composition } \\
\hline & 87.5 & organic matter & 93.0 \\
\hline crushed barley & 10.0 & crude protein & 15.0 \\
\hline rapeseed oilmeal & 1.0 & starch & 18.5 \\
\hline soyabean oilmeal & 1.0 & crude fibre & 24.0 \\
\hline \multirow[t]{5}{*}{ vitamin-mineral premix ${ }^{1}$} & 0.5 & NDF & 55.0 \\
\hline & & $A D F$ & 31.0 \\
\hline & & $A D L$ & 5.0 \\
\hline & & cellulose & 26.0 \\
\hline & & $\mathrm{UFV} \cdot \mathrm{kg}^{-1}$ & 5.4 \\
\hline
\end{tabular}

${ }^{1}$ Premix contents in $1 \mathrm{~kg}$ : IU: vit. A 700 000, vit. $\mathrm{D}_{3} 140000$, vit. E 1500; mg: Cu 30, Mn 60, Se 30, niacin 500; g: Ca 246, Na 80, P 20, Mg 30, S 1.2, Zn 1; DM - dry matter, NDF - neutral detergent fibre, ADF - acid detergent fibre, ADL - acid detergent lignin, UFV - feed unit of maintenance and meat production

(whole rumen contents), which included both the liquid and solid fractions, were taken by hand from different rumen sacs (approximately $2 \mathrm{~kg}$ ) followed by precise mixing and sampling. The material remaining after sampling was immediately returned to the rumen.

The samples for enzymatic analysis were frozen and kept at $-20^{\circ} \mathrm{C}$. Enzymes were extracted from the rumen content with phosphate buffer $(\mathrm{pH} 6.0), \mathrm{CCl}_{4}$ and lysozyme (Huhtanen and Khalili, 1992). In brief, the suspension was incubated for $4 \mathrm{~h}$ at $37^{\circ} \mathrm{C}$ and then centrifuged at $20000 \mathrm{~g}$ for $30 \mathrm{~min}$. The supernatant was collected and used as an enzyme source. The extracted enzyme preparation was incubated for $1 \mathrm{~h}$ at $40{ }^{\circ} \mathrm{C}$ with phosphate buffer ( $\mathrm{pH}$ 6.0) and purified substrates of either low viscosity carboxymethylcellulose (C-5678 Sigma-Aldrich, Sigma-Aldrich Co., St. Louis, MO, USA), beechwood xylan (X-4252 Sigma-Aldrich, Sigma-Aldrich Co., St. Louis, MO, USA), potato starch (Sigma-Aldrich S-2004, SigmaAldrich Co., St. Louis, MO, USA), pectin from citrus (P-9125 Sigma-Aldrich Sigma-Aldrich, SigmaAldrich Co., St. Louis, MO, USA) or colloidal chitin from shrimp shells (C-7170 Sigma-Aldrich, SigmaAldrich Co., St. Louis, MO, USA). The reaction was stopped by the addition of the dinitro-salicylic acid reagent and by denaturing enzyme proteins (heating at $100^{\circ} \mathrm{C}$ for $5 \mathrm{~min}$.). Reducing sugars were quantified spectrophotometrically at $560 \mathrm{~nm}$.

Feed samples were analysed for dry matter (934.01), crude protein (954.01), crude fibre (978.10), ADF and ADL (973.18), NDF (2002.04), starch (920.40), and ash (930.05) contents (AOAC, 2011).

\section{Statistical analysis}

Data were expressed as means and pooled standard error of mean values. The data were subjected to 
statistical analysis of variance for a factorial design using the general linear model (GLM). This model included as the main plot the effects of heifers, treatment, sampling time, and the interaction between treatment and sampling time. The model used was:

$$
\mathrm{Y}_{\mathrm{jkl}}=\mu+\mathrm{H}_{\mathrm{j}}+\operatorname{Trt}_{\mathrm{k}}+\mathrm{S}_{1}+(\operatorname{Trt}+\mathrm{S})_{\mathrm{kl}}+\varepsilon_{\mathrm{jkl}}
$$

where: $\mathrm{Y}-\mathrm{a}$ dependent variable, $\mu-$ the overall mean, $\mathrm{H}_{\mathrm{j}}-$ the heifers, $\mathrm{Trt}_{\mathrm{k}}-$ the treatment effect, $\mathrm{S}_{\mathrm{l}}$ - the sampling time effect, $(\mathrm{Trt}+\mathrm{S})_{\mathrm{kl}}-$ the interaction between treatments and sampling time, $\varepsilon_{\mathrm{jk} l}-$ the residual error.

Differences between treatment effects were assessed by pairwise comparisons (Tukey's test). Statements of statistical significance were based on $P \leq 0.05$ or $P<0.01$. The statistical analysis was performed using the Statistica 10.0 software package. (StatSoft Inc., 2011).

\section{Results and discussion}

Introduction of live $S$. cerevisiae into the rumen resulted in an increase in cellulolytic activity in ruminal digesta when compared with animals fed metabolites of yeast before and $4 \mathrm{~h}$ after feeding (Table 2 ). In contrast, yeast metabolites significantly decreased cellulolytic activity compared with heifers fed the control diet only at $8 \mathrm{~h}$ after feeding. This is in agreement with the results of Moharrery and Asadi (2009), who reported that the activity of cellulase increased in the rumen of sheep fed a combination of malate and live S. cerevisiae. Moreover, ElWaziry and Ibrahim (2007) reported that the in vitro activity of cellulase was enhanced by the addition of yeast cells during $4 \mathrm{~h}$ incubation. The live yeast cells added to theruminants' diets could increase the activity of cellulase because they stimulated the activity of cellulolytic bacteria, in particular of Fibrobacter succinogenes, Ruminococcus albus, as well as Ruminococcus flavefaciens (Chaucheyras et al., 1997). It can not be precluded that the increase in cellulolytic activity could result from an increase in the number of cellulolytic protozoa from the genus Diplodinium, e.g., Eudiplodinium maggii and Diploplastron affine, which are commonly present in the rumen of domestic ruminants (Michałowski et al., 2003). The authors found that up to $38 \%$ of total cellulolytic activity in the rumen originated from Eudiplodinium maggii, and that this contribution was visibly related to the number of ciliates. Kowalik et al. (2011) reported that live $S$. cerevisiae increase the degradability of structural carbohydrates of meadow hay in the rumen of goats. The authors suggest that live yeast can increase the number of total ciliates and those belonging to the genus Diplodinium. Moreover, Ding et al. (2014) showed that live yeast increased NDF effective degradability from lucerne pellets in steers. According to these authors, higher NDF degradability increased the number and activities of fibre-degrading bacteria. In contrast, Brossard et al. (2006) and Tripathi and Karim (2011) did not observe any increase in ruminal cellulolytic activity in sheep fed live S. cerevisiae. Sampling time and interaction $(\operatorname{Trt} \times \mathrm{S})$ did not affect cellulolytic activity because cellulose is degraded slowly over a long time (Table 2).

The activity of xylan-degrading enzymes in the rumen of heifers was significantly lower when animals were fed the diet supplemented with live yeast or yeast metabolites than when control feed was given (Table 2). In comparison with $0 \mathrm{~h}$, xylanolytic activity was significantly lower at 2, 4 and $8 \mathrm{~h}$ after feeding for control and both experimental groups. These findings suggest a negative effect of the yeast preparation on xylanolytic activity; fungal additives can, probably, inhibit digestibility of hemicellulose in the rumen. Similar effects were found by Tripathi and Karim, (2011), when sheep were fed a diet supplemented with live yeast. In contrast to our findings, Michalet-Doreau et al. (1997) showed that live $S$. cerevisiae increased the xylanolytic activity in the rumen of sheep.

The activity of amylase significantly increased before and $4 \mathrm{~h}$ after feeding when heifers were fed the diet supplemented with live yeast cells compared with animals fed the control diet and yeast metabolites (Table 2). Introducing the yeast preparation into the rumen resulted in decreased amylolytic activity when compared with control animals $8 \mathrm{~h}$ after feeding. Addition of live $S$. cerevisiae reduced this activity only at the last time point of sampling compared with 0,2 and $4 \mathrm{~h}$ after feeding. A significant treatment $\mathrm{x}$ time interaction was observed for amylase activity (Table 2). It is possible that starch was degraded in the rumen very fast over a short period after feeding. Moharrery and Asadi (2009) reported the tendency of amylolytic activity to increase when live yeast were introduced into sheep. According to Tripathi and Karim (2011), yeast culture supplementation increased the number of microbial cells in the rumen, which improved microbial enzyme status for feed fermentation. Moreover, the yeast preparation stimulated the growth of amylolytic and short-chain-polysaccharide-degrading microorganisms (Tripathi and Karim, 2011). In our study, the increase in amylolytic activity could have resulted from the increase in the number of 
Table 2. The activity of polysaccharidases $\left(\mu \mathrm{M}\right.$ released product $\left.\cdot \mathrm{g}^{-1} \mathrm{DM} \cdot \mathrm{min}^{-1}\right)$ in the rumen content of heifers

\begin{tabular}{|c|c|c|c|c|c|c|c|c|c|}
\hline \multirow{2}{*}{$\begin{array}{l}\text { Polysaccharidases } \\
\text { activities }^{1}\end{array}$} & \multirow{2}{*}{ Treatment } & \multicolumn{4}{|l|}{ Hour $^{2}$} & \multirow{2}{*}{ SEM } & \multirow{2}{*}{$\mathrm{Trt}^{3}$} & \multirow{2}{*}{$S^{3}$} & \multirow{2}{*}{$\operatorname{Trt} \times \mathrm{S}^{3}$} \\
\hline & & 0 & 2 & 4 & 8 & & & & \\
\hline \multirow[t]{3}{*}{ Cellulolytic } & Control & 11.6 & 10.9 & 10.5 & $11.8^{\mathrm{a}}$ & 0.27 & $<0.001$ & 0.122 & 0.221 \\
\hline & Live yeast & $12.0^{\mathrm{a}}$ & 10.3 & $11.7^{\mathrm{A}}$ & 10.1 & & & & \\
\hline & Yeast metabolites & $9.1^{\mathrm{b}}$ & 9.2 & $7.7^{\mathrm{B}}$ & $7.2^{\mathrm{b}}$ & & & & \\
\hline \multirow[t]{3}{*}{ Xylanolytic } & Control & $29.5^{\mathrm{A}}$ & $22.9_{y}^{A}$ & $25.4_{y}^{\mathrm{A}}$ & $27.2^{\mathrm{A}}$ & 0.49 & $<0.001$ & $<0.001$ & 0.039 \\
\hline & Live yeast & $24.6^{B} x$ & $20.6^{\mathrm{B}}{ }_{\mathrm{Y}}$ & $19.7_{\mathrm{Y}}^{\mathrm{B}}$ & $20.4_{Y}^{B}$ & & & & \\
\hline & Yeast metabolites & $23.9^{\mathrm{B}}$ & $20.2_{y}^{B}$ & $20.5_{y}^{B}$ & $19.1_{y}^{B}$ & & & & \\
\hline \multirow[t]{3}{*}{ Amylolytic } & Control & $11.6^{B} x$ & $22.5_{Y}$ & $16.1_{\mathrm{Y}}^{\mathrm{B}}$ & $16.3^{\mathrm{A}}$ & 0.61 & $<0.001$ & $<0.001$ & 0.002 \\
\hline & Live yeast & $19.7_{Y}^{A}$ & $20.6_{Y}$ & $19.8_{Y}^{A}$ & $12.3^{B} x$ & & & & \\
\hline & Yeast metabolites & $9.4^{B} x$ & $18.5_{Y}$ & $14.0_{\mathrm{Y}}^{\mathrm{B}}$ & $12.5^{\mathrm{B}}$ & & & & \\
\hline \multirow[t]{3}{*}{ Pectinolytic } & Control & $8.5^{\mathrm{B}}$ & $7.7^{\mathrm{b}}$ & $7.5^{\mathrm{B}}$ & $7.7^{\mathrm{b}}$ & 0.14 & $<0.001$ & 0.053 & 0.072 \\
\hline & Live yeast & $7.9^{\mathrm{B}}$ & 7.2 & $8.6^{\mathrm{B}}$ & 7.2 & & & & \\
\hline & Yeast metabolites & $6.7^{\mathrm{A}}$ & $6.3^{\mathrm{a}}$ & $5.9^{\mathrm{A}}$ & $6.2^{\mathrm{a}}$ & & & & \\
\hline \multirow[t]{3}{*}{ Chitinolytic } & Control & $2.0_{\mathrm{Y}}^{\mathrm{A}}$ & $1.5_{x}$ & $1.3_{x}$ & $1.3_{x}$ & 0.03 & 0.001 & $<0.001$ & 0.012 \\
\hline & Live yeast & $1.4^{\mathrm{B}}$ & $1.3^{\wedge}$ & $1.3^{\wedge}$ & $1.2^{\wedge}$ & & & & \\
\hline & Yeast metabolites & $1.4^{\mathrm{B}}$ & 1.3 & 1.3 & 1.3 & & & & \\
\hline
\end{tabular}

upper different superscripts ( ${ }^{\mathrm{A}, \mathrm{B}}$ and $\left.\mathrm{a,b}\right)$ indicate differences $(P<0.01$ and $P<0.05$, respectively) between treatments (control, live yeast and metabolites). Lower different subscript $(X, Y$ and $x, y)$ show differences $(P<0.01$ and $P<0.05$, respectively) between sampling time $(0,2,4$ and $8 \mathrm{~h}) ;{ }^{1}$ unit of polysaccharidases activities are: cellulolytic and amylolytic $\left(\mu \mathrm{M}\right.$ glucose released $\left.\cdot \mathrm{g}^{-1} \mathrm{DM} \cdot \mathrm{min}^{-1}\right) ; \mathrm{xylanolytic}(\mu \mathrm{M}$ xylose released $\left.\cdot \mathrm{g}^{-1} \mathrm{DM} \cdot \mathrm{g}^{-1}\right)$; pectinolytic $\left(\mu \mathrm{M}\right.$ glucuronic acid released $\left.\cdot \mathrm{g}^{-1} \mathrm{DM} \cdot \mathrm{min}^{-1}\right)$; chitinolytic $\left(\mu \mathrm{MN}\right.$-acetyl-D-glucosamine released $\left.\cdot \mathrm{g}^{-1} \mathrm{DM} \cdot \mathrm{min}^{-1}\right)$; ${ }^{2}$ samples were taken at 0, 2, 4, $8 \mathrm{~h}$ after morning feeding; SEM - standard error of mean; ${ }^{3} \mathrm{Trt}$ - main effect of treatment; S - main effect of time; Trt x S - treatment time interaction effect

amylolytic bacteria (Kmet' et al., 1992) and protozoa (Ding et al., 2014). Brossard et al. (2006) demonstrated that addition of live $S$. cerevisiae to the diet for sheep stimulated the growth of ciliates from the Ophryoscolecidae family in the rumen. Supplementation of the diet with live yeast increased the numbers of ciliates from the genus Entodinium (Ophryoscolecidae family) (Kowalik et al., 2008). Ciliates belonging to the species Entodinium caudatum ingest and digest starch (Michałowski et al., 2003) and probably are also responsible for the increase in amylolytic activity.

Supplementation of the diet with yeast metabolites significantly decreased pectinolytic activity compared with animals fed the control diet, before and after feeding (Table 2). Moreover, this activity was lower in heifers fed yeast metabolites than those given live yeast, 0 and $4 \mathrm{~h}$ after feeding. The preparation of yeast metabolites is a commercial product. It contains various components influencing ruminal microorganisms. In our study, these components were probably able to suppress the pectinolytic microorganism count in the rumen of heifers.

Furthermore, the preparation of yeast added to the diets decreased chitinolytic activity before the morning feeding compared with the animals fed the control diet. Chitinolytic activity was higher at $0 \mathrm{~h}$ compared with any time after feeding for the control group (Table 2). The cell wall of ruminal fungi, as well as the yeast preparation, is rich in chitin. Chitin is a source of energy for ruminal microorganisms: bacteria, Clostridium (Kopečný and Hodorová, 2000) and ciliates, Entodinium caudatum, Eudiplodinium maggi, Diploplastron affine (Bełżecki et al., 2011). In the current study, the effect of the yeast, S. cerevisiae, on chitinolytic activity was very small; this effect is difficult to explain. Probably, the chitin contained in the cell wall of yeast was inaccessible for microorganisms in the rumen.

\section{Conclusions}

Live Saccharomyces cerevisiae may increase the cellulolytic and amylolytic activity in the rumen of heifers before and $4 \mathrm{~h}$ after feeding. Supplementation of the diet with the yeast preparation in both forms decreased xylanolytic activity; the addition of yeast metabolites reduced pectinolytic activity after feeding. Our results suggest that live yeast and their metabolites might alter polysaccharidase activities in the rumen, however, the results are not unequivocal and further studies are needed to explain their influence more precisely. 


\section{References}

AOAC, 2011. Association of Official Analytical Chemists, Official Methods of Analysis. $18^{\text {th }}$ Edition. Arlington, VA

Bełżecki G., Miltko R., Michałowski T., 2011. Chityn, a potential source of energy for rumen ciliates and their host. Ann. Report, Polish Academy of Sciences, Agric. Forest Vet. Sci, pp. 76-78

Brossard L., Chaucheyras-Durand F., Michalet-Doreau B., Martin C. 2006. Dose effect of live yeasts on rumen microbial communities and fermentations during butyric latent acidosis in sheep: new type of interaction. Anim. Sci. 82, 829-836

Callaway E.S., Martin S.A., 1997. Effects of Saccharomyces cerevisiae culture on ruminal bacteria that utilize lactate and digest cellulose. J. Dairy Sci. 80, 2035-2044

Chaucheyras F., Millet L., Michalet-Doreau B., Fonty G., Bertin G., Gouet P., 1997. Effect of the addition of Levucell ${ }^{\circledR}$ SC on the rumen microflora of sheep during adaptation to high starch diets. Reprod. Nutr. Develop. 37, 81-82

El-Waziry A.M., Ibrahim H.R., 2007. Effect of Saccharomyces cerevisiae of yeast on fiber digestion in sheep fed berseem (Trifolium alexandrium) hay and cellulase activity. Aust. J. Basic Appl. Sci. 1, 379-385

Ding G., Chang Y., Zhao L., Zhou Z., Ren L., Meng Q., 2014. Effect of Saccharomyces cerevisiae on alfalfa nutrient degradation characteristic and rumen microbial populations of steers fed diets with different concentrate-to-forage ratios. J. Anim. Sci. Biotechnol. 5, 24, doi: 10.1186/2049-1891-5-24

Huhtanen P., Khalili H.,1992. The effect of sucrose supplements on particle-associated carboxymethylcellulase (EC 3.2.1.4) and xylanase (EC 3.2.1. 8) activities in cattle given grass-silagebased diet. Brit. J. Nutr. 67, 245-255

Kmet' V., Jonecová Z., Stachová M., 1992. The effect of pectinolytic yeast on rumen microflora. J. Anim. Feed Sci. 1, 165-170
Kopečný J., Hodrová B., 2000. Chitinolytic enzymes produced by ovine rumen bacteria. Folia Microbiol. Prague 45, 465-468

Kowalik B., Michałowski T., Pająk J.J., Taciak M., Rawa J., 2008. The effect of supplementing cows with live yeast Saccharomyces cerevisiae, on ciliate fauna and ruminal fermentation. J. Anim. Feed Sci. 17, 157-165

Kowalik B., Michałowski T., Pajak J.J., Taciak M., Zalewska M., 2011. The effect of live yeast, Saccharomyces cerevisiae, and their metabolites on ciliate fauna, fibrolytic and amylolytic activity, carbohydrate digestion and fermentation in the rumen of goats. J. Anim. Feed Sci. 20, 526-536

Michalet-Doreau B., Morand D., Martin C., 1997. Effect of the microbial additive Levucell ${ }^{\circledR} \mathrm{SC}$ on microbial activity in the rumen during the stepwise adaptation of sheep to high concentrate diet. Reprod. Nutr. Develop. 37, Suppl. 1, 81-82

Michałowski T., Bełżecki G., Kwiatkowska E., Pająk J.J., 2003. The effect of selected rumen fauna on fibrolytic enzyme activities, bacterial mass, fibre disappearance and fermentation pattern in sheep. J. Anim. Feed Sci. 12, 45-64

Moharrery A., Asadi E., 2009. Effects of supplementing malate and yeast culture (Saccharomyces cerevisiae) on the rumen enzyme profile and geowth performance of lambs. J. Anim. Feed Sci. 18, 283-295

Newbold C.J., Wallace R.J., McIntosh F.M., 1996. Mode of action of the yeast Saccharomyces cerevisiae as a feed additive for ruminants. Brit. J. Nutr. 76, 249-261

StatSoft, Inc. STATISTICA, 2011. Data analysis software system, ver. 10. www.statsoft.com

Tripathi M.K., Karim S.A., 2011. Effect of yeast cultures supplementation on live weight change, rumen fermentation, ciliate protozoa population, microbial hydrolytic enzymes status and slaughtering performance of growing lamb. Livest. Sci. 135, $17-25$ 